\title{
Right and Wrong Approaches To Colorectal Anastomotic Strictures: When? Which Technique?
}

\author{
(1) Selçuk Kaya, (ㄱ) Yunus Emre Altuntaş, (ㅇ) Önder Altın, (1) Ahmet Şeker, \\ 마 Hasan Ediz Sıkar, (10 Kenan Çetin, (1) Nejdet Bildik, (ㄴ) Hasan Fehmi Küçük
}

Department of General Surgery, Health Sciences University, Kartal Dr. Lütfi Kırdar Training and Research Hospital, İstanbul, Turkey

Submitted: 21.04 .2018 Accepted: 11.05 .2018

Correspondence: Selçuk Kaya, Kartal Dr. Lütfi Kırdar Eğitim ve Araştırma Hastanesi, Genel Cerrahi Kliniği, İstanbul, Turkey E-mail: selcukkaya_36@hotmail.com

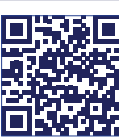

Keywords: Anastomosis; colorectal; dilatation; stricture.

\section{ABSTRACT}

Objective: The aim of this study was to examine and describe the efficiency of endoscopic balloon and bougie dilatation techniques applied to anastomotic strictures developed in patients who underwent a low anterior resection (LAR) and ileostomy.

Methods: A total of 167 patients underwent an LAR with an ileostomy due to rectal cancer between July 2014 and December 20I7. Nineteen (\%II.4) cases with anastomosis stricture were retrospectively evaluated and included in the study. Patients were classified according to the dilation time. Group I patients received dilatation within the first 3 months postoperatively, and Group 2 patients received dilatation after 3 months. Demographic data, the dilatation technique, the number of dilatation applications, the level of the stricture, the success rate, and the stoma closure time were evaluated.

Results: In Group I, the mean number of dilatation procedures was I.8 (range: 1-3), whereas in Group 2, the mean was 3.8 (range: $2-5$ ). The success rate was 100\% in Group I and $66.6 \%$ in Group 2 . There was a statistically significant difference between the groups in the requirement for dilatation and the success rate $(p=0.022, p=0.028$, respectively).

Conclusion: It was concluded that dilatation techniques are most successful when applied within 3 months after surgery in cases with stenotic anastomoses. The risk of strictures and the number of repeated dilatations was lower and the success rate was significantly higher in these cases.

\section{INTRODUCTION}

One of the most common complications after colorectal surgery is benign anastomotic stricture. The incidence of postoperative colorectal anastomotic stricture has been reported as approximately $30 \% .^{[1-4]}$ Although the pathophysiology and causes of stricture are still not fully understood, it has been reported that factors such as anastomosis with stapler use, anastomotic leak, intestinal ischemia, and radiotherapy may be influential..$^{[5-7]}$ Clinically, the presence of radiological findings with symptoms of obstruction and the inability to pass a 12-mm diameter sigmoidoscope through the anastomosis was defined as anastomotic stenosis. ${ }^{[8]}$ Anastomotic stenosis occurring after per- forming anastomosis with a stapler was significantly more common than following manual anastomosis. ${ }^{[9,10]}$ Patients with symptomatic post-anastomotic stricture without a diversion ileostomy typically present with complaints of cramp-like abdominal pain, constipation, diarrhea, fecal incontinence, and bleeding. ${ }^{[1]}$ However, in patients with a diversion ileostomy, these complaints are almost never seen. In these patients, anastomotic stricture is usually detected incidentally in a late-stage control colonoscopy performed before the closure of the stoma. If anastomosis is present in the lower part of the rectum, management with direct digital dilatation, dilatation with an endoscopic balloon or bougie is possible. 
Balloon dilation is the best method for cases with anastomotic stricture at other levels. Transanal endoscopic balloon dilatation is a frequently used technique with low morbidity and mortality rates. ${ }^{[12,13]}$ Anastomotic strictures that do not respond to these noninvasive procedures are frequently operated on. However, these procedures have serious morbidity and mortality rates, and major complications of up to $18 \%$ have been reported. ${ }^{[14]}$ In our study, we evaluated the success of early and late endoscopic balloon and bougie dilatation techniques applied to anastomotic strictures in patients with a low anterior resection (LAR) with a diversion ileostomy due to colorectal cancer.

\section{MATERIAL AND METHODS}

The ethics committee of Dr. Lutfi Kirdar Kartal Education and Research Hospital granted approval for this study (Decision No: 2018/5 I4/I25/4; Date: 03.14.2018).

Between July 2014 and December 2017, 167 patients underwent LAR with a diversion ileostomy in our clinic due to a rectal tumor. The records of 19 (I I.4\%) patients with anastomotic stricture were retrospectively reviewed. The patients were divided into 2 groups: Group I underwent dilatation within 3 months after the procedure and Group 2 underwent dilatation later. The groups were evaluated according to demographic findings, dilatation technique, the number of dilation procedures, the location of the stricture, the success rate, and the stoma closure time. Cases of anastomotic stricture due to leakage and stricture of the colonic lumen larger than $20 \mathrm{~mm}$ that allowed passage of a colonoscope were excluded from the study.

A biopsy from the anastomotic line was obtained to verify that all of the patients with anastomotic stricture that did not allow a 12-mm colonoscope to pass through on initial evaluation had no tumor recurrence. Though there was no recurrent mass observed on a control pelvic magnetic resonance image, an hourglass-shaped concentric constriction on the anastomotic line was observed. Endoscopic dilation was performed as an outpatient procedure under sedation with midazolam $(5-10 \mathrm{mg})$ and pethidine hydrochloride $(50 \mathrm{mg})$ following rectal enema.

Management of stenosis was performed using I of 3 methods: bougie/digital dilatation under general anesthesia in the operating room, radiologically guided balloon dilatation, or balloon dilatation under sedation during an endoscopy.

In our endoscopy unit, stenosis occurring above the upper part of the anal verge was examined with an endoscope and the length of the narrow segment was observed using a contrast agent administered through a 22-F Foley catheter inserted distal to the narrow region. Dilatation with an over-the-wire (OTW) balloon rather than a through-the-scope balloon was preferred as it is more reliable and highly successful.

After passing a 14-F guidewire through the narrow anastomosis line, a 10-cm OTW balloon with a diameter of 35 $\mathrm{mm}$ was advanced over the guidewire and, under direct vision, was positioned and inflated at an appropriate pressure with diluted radiopaque material. Then, under fluoroscopic control, it was determined that the dilatation was successful and performed in the right place. In each session, the dilation balloon was slowly inflated with diluted radiopaque material twice for 3 minutes and the pressure was increased gradually to $150-200 \mathrm{kPa}$ (Fig. Ia-c).

Balloon dilatation or digital dilatation was applied after dilatation with Savary-Gilliard (Rene Gilliard, St. Sulpice, Switzerland) bougies in cases of a distal anastomotic stricture narrower than $5 \mathrm{~mm}$.

The procedures were repeated a few days later when required according to endoscopic findings. The success of endoscopic balloon, digital, or bougie dilatation was defined based on clinical improvement and smooth passage of a colonoscope $(20 \mathrm{~mm})$. The duration, number of dilatations, and success rates of the procedures were evaluated.

An Excel worksheet (Microsoft Corp., Redmond, WA) was used to enter data and statistical analysis was carried out using the Statistical Package for Social Sciences software (SPSS Inc. ver. 13.0, Chicago, IL, USA). All statistical analyses were calculated with the help of chi-square for non
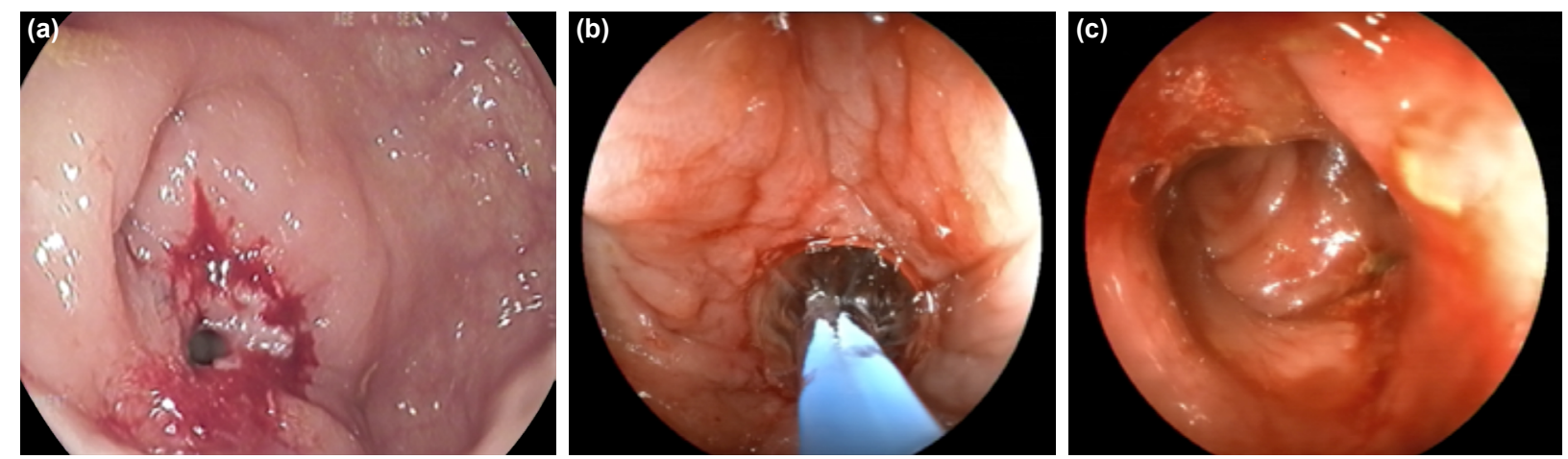

Figure 1. (a) Stenosis of anastomosis before dilatation, (b) balloon dilatation, (c) appearance following dilatation. 
parametric values, whereas Student t-test was applied for evaluation of parametric values. Based on the results of the analyses, a p-value $<0.05$ was considered as statistically significant.

\section{RESULTS}

Of the 19 patients who developed anastomotic strictures, $15(78.9 \%)$ were male and $4(21.1 \%)$ were female. The mean age of the patients was 58.5 years (range: 37-77 years). No statistically significant difference was found between the 2 groups in terms of gender or age $(p=0.480$, $p=0.327$, respectively). All of the patients in this study had neoadjuvant chemoradiotherapy and all of the patients underwent a diversion ileostomy with anastomosis using a circular stapler. Dilation performed before or after the third postoperative month was the basis for the formation of the 2 study groups.

The I 3 patients (68.4\%) in Group I who underwent dilatation within 3 months required an average of 1.8 dilations (range: 1-3 dilations) while the 6 patients (31.6\%) in Group 2 required 3.8 dilatations (range: $2-5$ dilations). There was a statistically significant difference in the need for dilation between the groups $(p=0.022)$.

In $8(61.5 \%)$ of the 13 patients in Group I, the level of

Table I. Demographic and clinical characteristics of the patients according to group

\begin{tabular}{|c|c|c|c|}
\hline & Group I & Group 2 & $\mathbf{p}$ \\
\hline Gender & & & 0.480 \\
\hline Female & 4 & I & \\
\hline Male & 9 & 5 & \\
\hline Age (years) & $\begin{array}{c}52.23 \\
(37-77)\end{array}$ & $\begin{array}{c}61.17 \\
(52-76)\end{array}$ & 0.327 \\
\hline Dilatation & & & 0.370 \\
\hline Bougie dilatation & 7 & 2 & \\
\hline Balloon dilatation & 6 & 4 & \\
\hline Number of dilatations & $\begin{array}{l}1.85 \\
(I-3)\end{array}$ & $\begin{array}{l}3.83 \\
(2-5)\end{array}$ & 0.022 \\
\hline $\begin{array}{l}\text { Time to ostomy closure } \\
\text { (months) }\end{array}$ & $\begin{array}{l}5.00 \\
(3-7)\end{array}$ & $\begin{array}{l}8.50 \\
(5-13)\end{array}$ & 0.105 \\
\hline $\begin{array}{l}\text { Level of stricture } \\
\text { (distance to anal verge) }\end{array}$ & & & 0.259 \\
\hline$\leq 4 \mathrm{~cm}$ & 8 & 2 & \\
\hline$>4 \mathrm{~cm}$ & 5 & 4 & \\
\hline Outcome of dilatations & & & 0.028 \\
\hline Successful & 13 & 4 & \\
\hline Unsuccessful & - & 2 & \\
\hline
\end{tabular}

anastomosis was within $4 \mathrm{~cm}$ of the anal verge, whereas in 5 patients $(38.5 \%)$ it was between 5 and $9 \mathrm{~cm}$ from the anal opening. The anastomosis of the patients in Group 2 was within $4 \mathrm{~cm}$ of the anal verge in 2 patients (33.3\%) and 5 to $9 \mathrm{~cm}$ in 4 patients (66.6\%). In Group I, 4 underwent bougie/digital dilatation, and 2 patients had the procedure performed in Group 2. In Group I, 5 patients underwent balloon dilatation, and 4 patients underwent balloon dilatation in Group 2. The median time to stoma closure was 5 months (range: 3-7 months) and 8.5 months (range: 5-13 months) in Group I and 2, respectively $(p=0.105)$.

The success rate of dilatation in Group I and 2 was 100\% and $66.6 \%$, respectively. There was a statistically significant difference in the results of dilatation between the 2 groups $(p=0.028)$. In Group 2, the follow-up of 2 patients with failed dilatation results continues (Table I). There were no complications during dilatation in either group.

\section{DISCUSSION}

Anastomotic stricture at the level of the anal canal and above is defined as narrowing of the lumen that does not allow passage of a colonoscope after colorectal surgery. ['I] Tissue ischemia, inflammation, anastomotic leakage, and radiotherapy have been suggested as the most frequent etiological agents..$^{[3,15]}$ The rate of stapler-induced anastomotic stenosis was significantly greater than for manual anastomosis. ${ }^{[14]}$ Male gender, the use of staples, and divergent stoma have been reported as prognostic factors in the development of anastomotic stricture. ${ }^{[6,17]}$ In some studies, it has been said that anastomoses under the peritoneal reflection are associated with a greater risk of stenosis. ${ }^{[18]}$

In the past, surgical treatment was applied for all anastomotic strictures unresponsive to medical treatment; however, currently, noninvasive endoscopic methods have become more prominent. ${ }^{[19]}$ Noninvasive methods include dilatation with polyvinyl bougies or a balloon, and the use of metallic stents in unsuccessful cases. ${ }^{[12,20,21]}$ In some cases, along with these, an incision made with an Nd: YAG laser or or an endoscopic retrograde cholangiopancreatography precut needle may increase the success of dilatation and reduce the risk of perforation. ${ }^{[22,23]}$ In these patients, 2 or 3 small radial electroincisions are performed under endoscopic view and balloon dilation is performed for 15 to 20 minutes. ${ }^{[24]}$ The pressure created by the balloon dilation radiates outwardly. As a result, the force of dilatation is exerted solely on the stricture site and the risk of tearing seen with rigid bougies is reduced to a minimum. ${ }^{\left[{ }^{I I]}\right.}$ In cases where endoscopic treatment is considered, a biopsy should be taken from the anastomosis line to rule out tumor recurrence.

Patients with symptomatic anastomotic stricture without 
a diversion ileostomy typically present with cramp-like abdominal pain, constipation, diarrhea, fecal incontinence, and bleeding. ${ }^{\left[{ }^{[1]}\right]}$ However, in patients with a diversion ileostomy, these complaints are rarely seen related to anastomotic stricture. In these patients, anastomotic stenosis is typically detected incidentally in a late-stage control colonoscopy performed before the closure of the stoma.

In our study, all of the patients had a protective stoma. Anastomotic stenosis was detected coincidentally during a colonoscopic evaluation before stoma closure. Complete success was achieved in the dilatation of anastomotic strictures in all of the patients in whom it was detected within the first 3 months after surgery (Group I). The success rate was $66.6 \%$ for patients who underwent a colonoscopy more than 3 months postoperatively (Group 2). There was a statistically significant difference between the 2 groups in terms of the need for re-dilatation and success $(p=0.022, p=0.028$, respectively). Dilatation failure in 2 patients in Group 2 in our study was associated with postoperative dilatation performed more than 3 months postoperatively (late). It has been reported in the literature that the failure rate is higher in dilatations performed after the fourth postoperative month. ${ }^{[5]}$

In conclusion, we think that dilatation procedures performed within the first 3 months after surgery for anastomotic narrowing decreased the risk of stricture, decreased the recurrence of dilatation, and increased dilatation success rates in our study. But there is a need for high-volume studies to support these findings.

Ethics Committee Approval

Approved by the local ethics committee (Decision No: 2018/5 I4/I25/4; Date: 03.14.20I8).

Informed Consent

Retrospective study.

Peer-review

Internally peer-reviewed.

Authorship Contributions

Concept: S.K., Y.E.A., Ö.A., A.Ş., H.E.S., K.Ç., N.B., H.F.K.; Design: S.K., Y.E.A., Ö.A., A.Ş., H.E.S., K.Ç., N.B., H.F.K.; Data collection \&/or processing: S.K, Y.E.A., Ö.A., A.Ş., H.E.S., K.Ç., N.B., H.F.K.; Analysis and/or interpretation: S.K., Y.E.A., Ö.A., H.F.K.; Literature search: S.K., Ö.A., H.E.S., K.Ç.; Writing: S.K., Y.E.A., Ö.A., H.E.S.; Critical review: S.K., Y.E.A., N.B., H.F.K.

Conflict of Interest

None declared.

\section{REFERENCES}

1. Kissin MW, Cox AG, Wilkins RA, Kark AE. The fate of the EEA stapled anastomosis: a clinico-radiological study of 38 patients. Ann R Coll Surg Engl 1985;67:20-2.
2. Schlegel RD, Dehni N, Parc R, Caplin S, Tiret E. Results of reoperations in colorectal anastomotic strictures. Dis Colon Rectum 2001;44:1464-8. [CrossRef]

3. Max E, Sweeney WB, Bailey HR, Oommen SC, Butts DR, Smith $\mathrm{KW}$, et al. Results of 1,000 single-layer continuous polypropylene intestinal anastomoses. Am J Surg 1991;162:461-7. [CrossRef]

4. Hiranyakas A, Da Silva G, Denoya P, Shawki S, Wexner SD. Colorectal anastomotic stricture: is it associated with inadequate colonic mobilization? Techn Coloproctol 2013;17:371-5. [CrossRef]

5. Neutzling CB, Lustosa SA, Proenca IM, da Silva EM, Matos D. Stapled versus handsewn methods for colorectal anastomosis surgery. Cochrane Database Syst Rev 2012:CD003144. [CrossRef]

6. Orsay CP, Bass EM, Firfer B, Ramakrishnan V, Abcarian H. Blood flow in colon anastomotic stricture formation. Dis Colon Rectum 1995;38:202-6. [CrossRef]

7. Senagore A, Milsom JW, Walshaw RK, Dunstan R, Mazier WP, Chaudry IH. Intramural $\mathrm{pH}$ : a quantitative measurement for predicting colorectal anastomotic healing. Dis Colon Rectum 1990;33:175-9.

8. Kan H, Furukawa K, Suzuki H Tsuruta H, Matsumoto S, Akiya Y, et al. An improvement in the quality of life after performing endoscopic balloon dilation for postoperative anastomotic stricture of the rectum. J Nippon Med Sch 2007;74:418-23. [CrossRef]

9. Luchtefeld, MA, Milsom JW, Senagore A, Surrell JA, Mazier WP. Colorectal anastomotic stenosis. Results of a survey of the ASCRS membership. Dis Colon Rectum 1989;32:733-6. [CrossRef]

10. MacRae HM, McLeod RS. Handsewn vs. stapled anastomoses in colon and rectal surgery: a meta-analysis. Dis Colon Rectum 1998;41:180-9. [CrossRef]

11. Di Giorgio P, De Luca L, Rivellini G, Sorrentino E, D'amore E, De Luca B. Endoscopic dilation of benign colorectal anastomotic stricture after low anterior resection: A prospective comparison study of two balloon types. Gastrointest Endosc 2004;60:347-50. [CrossRef]

12. Delaunay-Tardy K, Barthelemy C, Dumas O, Balique JG, Audigier JC. Endoscopic therapy of benign colonic post-operative strictures: report on 27 cases [Article in French]. Gastroenterol Clin Biol 2003;27:610-13.

13. Pietropaolo V, Masoni L, Ferrara M, Montori A. Endoscopic dilation of colonic postoperative strictures. Surg Endosc 1990;4:26-30.

14. Genser L, Manceau G, Karoui M, Breton S, Brevart C, Rousseau G, et al. Postoperative and long-term outcomes after redo surgery for failed colorectal or coloanal anastomosis: retrospective analysis of 50 patients and review of the literature. Dis Colon Rectum 2013;56:747-55.

15. Lefevre JH, Bretagnol F, Maggiori L, Ferron M, Alves A, Panis Y. Redo surgery for failed colorectal or coloanal anastomosis: a valuable surgical challenge. Surgery 2011;149:65-71. [CrossRef]

16. Lustosa SA, Matos D, Atallah AN, Castro AA. Stapled versus handsewn methods for colorectal anastomosis surgery. Cochrane Database Syst Rev 2001:CD003144.

17. Waxman BP, Ramsay AH. The effect of stapler diameter and proximal colostomy on narrowing at experimental circular stapled large bowel anastomoses. Aust N Z J Surg 1986;56:797-801. [CrossRef]

18. Lucha PA Jr, Fticsar JE, Francis MJ. The strictured anastomosis: successful treatment by corticosteroid injections-report of three cases and review of the literature. Dis Colon Rectum 2005;48:862-5.

19. Yaman İ, Derici H. Endoscopic dilatation of benign colon anastomotic stricture: A case report. Turk J Colorectal Dis 2010;20:134-8.

20. Werre A, Mulder C, van Heteren C, Bilgen ES. Dilation of benign strictures following low anterior resection using Savary-Gilliard bougies. Endoscopy 2000;32:385-8. [CrossRef] 
21. 15. Solt J, Hertelendi A, Szilágyi K. Balloon catheter dilatation of lower gastrointestinal tract stenoses: long-term results [Article in Hungarian]. Orv Hetil 2002;143:1835-40.

22. Dieruf LM, Prakash C. Endoscopic incision of a postoperative colonic stricture. Gastrointest Endosc 2001;53:522-4. [CrossRef]

23. Truong S, Willis S, Schumpelick V. Endoscopic therapy of benign anastomotic strictures of the colorectum by electroincision and balloon dilatation. Endoscopy 1997;29:845-9. [CrossRef]

24. Hoffmann JC, Heller F, Faiss S, von Lampe B, Kroesen AJ, Wahnschaffe $\mathrm{U}$, et al. Through the endoscope balloon dilation of ileocolonic strictures: prognostic factors, complications, and effectiveness. Int J Colorectal Dis 2008;23:689-96. [CrossRef]

\section{Kolorektal Anastomoz Darlıklarına Yaklaşımda Doğrular ve Yanlışlar: Ne Zaman? Hangi Teknik?}

Amaç: Low anterior rezeksiyon (LAR) ve saptırıcı ileostomi yaptığımız hastalarda gelişen anastomoz darlıklarına uyguladığımız erken ve geç dönem endoskopik balon ve buji dilatasyon tekniklerinin başarısını irdelemek.

Gereç ve Yöntem: Temmuz 20I4-Aralık 2017 tarihleri arasında kliniğimizde rektum tümörü nedeniyle I67 hastaya LAR ve saptırıcı ileostomi yapıldı. Anastomoz darlığı gelişen 19 (\%। I.4) hastanın kayıtları geriye dönük olarak irdelendi. Ameliyat sonrası üçüncü aya kadar ilk dilatasyon uygulanan hastalar (Grup I) ve üçüncü aydan daha geç dilatasyon uygulananlar (Grup 2) şeklinde iki gruba ayrılarak, hastaların demografik bulguları, dilatasyon teknikleri, dilatasyon uygulama sayıları, darlık seviyeleri, başarı oranları ve stoma kapatılma süreleri değerlendirildi.

Bulgular: Grup I'de ortalama I.8 (I-3) kez dilatasyon gereksinimi olurken, Grup 2'de 3.8 (2-5) kez dilatasyon gereksinimi oldu. Grup I'de dilatasyon uygulananlarda başarı oranı \% 100 iken, Grup 2'de \%66.6 idi. Her iki grup arasında sırasıyla dilatasyon gereksinimi ve başarısı açııından istatistiksel olarak anlamlı fark tespit edildi $(p=0.022,0.028)$.

Sonuç: Çalışmamızda anastomoz darlıklarında ameliyat sonrası ilk üç ay içinde yapılan dilatasyon işlemlerinin striktür riskini düşüreceği buna bağlı olarak da dilatasyon tekrar sayısını azaltacağı ve dilatasyon başarı oranlarını artıracağı kanaatindeyiz.

Anahtar Sözcükler: Erken evre akciğer kanseri; küçük hücre dışı akciğer kanseri; stereotactic radyoterapi. 